\title{
MODIFIKASI TENAGA POMPA MENJADI SISTEM HAMPA UDARA PADA ALAT VERTIKULTUR
}

\author{
Modification The Pump Energy Into Vacum Systems Toward Vertikultur Device \\ Hilmaturrifqi YJ 1) Subari Yanto 2) dan Patang ${ }^{3)}$ \\ ${ }^{1}$ Alumni Program Studi Pendidikan Teknologi Pertanian \\ 1) 2 dan ${ }^{3}$ Dosen PTP FT UNM \\ hilmaturrifqiyj@gmail.com
}

\begin{abstract}
ABSTRAK
Penelitian ini bertujuan untuk mengetahui kapasitas distribusi input dan output air pada tempat penampungan hampa udara serta pengaruh sistem budidaya pada pengembangan alat vertikulturtenaga pompa.Penelitian ini merupakan penelitian rancang bangun. Data yang dikumpulkan terdiri dari tekanan hidrostatis $(P)$, kapasitas distribusi input dan output air, debit air, tinggi tanaman dan produksi tanaman. Data dianalisis dengan analisa deskriptif. Hasil penelitian menunjukkan terjadinya sirkulasi air karena $P_{1}>P_{2}$ dengan nilai masing-masing tekanan $P_{1} 4900 \mathrm{~kg} / \mathrm{ms}^{2}$ dan $P_{2} 1960 \mathrm{~kg} / \mathrm{ms}^{2}$, rata-rata kapasitas distribusi input $202.5 \mathrm{ml} / \mathrm{dt}$ sedangkan kapasitas distribusi output air sebesar $184.5 \mathrm{ml} / \mathrm{dt}$, debit air rata-rata selama penelitian output $0.32 \mathrm{ml} / \mathrm{det}$ dan input $0.39 \mathrm{ml} / \mathrm{dt}$. Alat ini selanjutnya di aplikasikan ke tanaman kangkung.

Kata Kunci : Modifikasi, Pompa, Hampa Udara, Vertikultur
\end{abstract}

\begin{abstract}
This study aimed to determine distributioninput and output capacity of water on the vacuums' shelter and the impact of cultivation system in developing vertikultur device of pumpenergy. This research is a design building. The data that collected consist of hydrostatic pressure $(P)$, input and output capacity of water distribution, water discharge, plant height and plant production. The data was analyzed by using descriptive analysis. The results showed that the water circulation occurred because $P_{1}>P_{2}$ with the value of each pressure was $P_{1} 4900 \mathrm{~kg} / \mathrm{ms}^{2}$ and $P_{2} 1960 \mathrm{~kg} / \mathrm{ms}^{2}$, the average of inputdistribution capacity was $202.5 \mathrm{ml} / \mathrm{sec}$ while the distribution of water output capacity was $184.5 \mathrm{ml} /$ $\mathrm{sec}$, the average of water discharge as long as output experiment was 0,32 $\mathrm{ml} / \mathrm{sec}$ and input 0,39 ml/sec. Then this device was applied to the kale plant.
\end{abstract}

Keywords: Modification, Pump, Vacuum, Vertikultur

\section{PENDAHULUAN}

Teknologi pada pembudidayaan baik itu tanaman atau ikan saat ini sudah banyak berkembang. Salah satu rekayasa teknologi yang banyak dijumpai yaitu teknologi pembuatan media tanam dengan sistem budidaya secara vertikultur. Munculnya teknologi tersebut dikarenakan adanya masalah pada lahan yang kini sangat minim sebab banyaknya lahan yang dimanfaatkan untuk tempat pemukiman khususnya di daerah perkotaan. 
Menurut Balai Pengkajian

Teknologi Pertanian Jawa Tengah (2006) lahan sempit yang banyak terdapat di perkotaan dapat dimanfaatkan dengan bertanam secara vertikal atau vertikultur. Budidaya pertanian di pekarangan khususnya di perkotaan, memiliki karakteristik yang khas. Kekhasan tersebut diantaranya karena luas lahan yang sempit. Optimasi pemanfaatan pekarangan dalam budidaya tanaman dan sumber bahan pangan di perkotaan sangat perlu dilakukan (BPTP Jakarta, 2013).

model vertikultur dengan sistem hidroponik cocok untuk daerah perkotaan dan lahan terbatas serta memanfaatkan penggunaan air (Lukman, 2008). Tujuan utama penerapan teknik vertikultur adalah memanfaatkan lahan sempit seoptimal mungkin. Dengan menerapkan teknik vertikultur ini maka peningkatan jumlah tanaman pada suatu areal tertentu dapat berlipat 3-10 kali, tergantung model yang digunakan (Andoko, 2004 dalam Nilam, 2015). Namun, pembudidayaan tanaman model vertikultur dengan sistem hidroponikpada umumnya masih menggunakan mesin pompa air yang mengunakan energi listrik untuk menggerakkan mesin pompa air tersebut, sehingga memerlukan biaya yang cukup besar.

Untuk menghemat dan mengefisienkan penggunaan biaya serta tenaga, diperlukan inovasi baru yaitu dengan memodifikasi tenaga mesin pompa air menjadi sistem hampa udara pada alat vertikultur. Dengan memanfaatkan ruang hampa udara diharapkan mampu menaikkan air dari sumber air ke wadah pembudidayaan tanaman sebagai pengganti tenaga pompa air untuk mengairi tanaman.

\section{TUJUAN PENELITIAN}

\author{
Pada penelitian ini membuat \\ sebuah rancang bangun untuk \\ mengetahui kapasitas distribusi input dan \\ output air yang berhubungan dengan \\ tekanan hidrostatis $(P)$, volume (V), debit \\ (Q) serta pengaruh sistem budidaya \\ terhadap produksi tanaman kangkung \\ dalan pengembangan alat vertikultur \\ tenaga pompa menjadi sistem hampa \\ udara.
}

\section{METODE PENELITIAN}

Penelitian ini merupakan penelitian rekayasa atau rancangbangun. Penelitian ini dilakukan mulai dari perencanaan yaitu membuat desain gambar serta kebutuhan-kebutuhan untuk perakitan alat. Dalam perakitan alat vertikultur sistem hampa udara dibutuhkn alat dan bahan diantaranya kayu, pipa kapiler, selang plastik, paku, wadah plastik, botol plastik, lem tembak, gergaji tangan dan palu, kemudian dilakukan proses perakitan alat. Untuk mengetahui kinerja dari alat maka dilakukan uji kapasitas distribusi airinputdan output dari wadah sumber air ke wadah penampungan hampa udara (botol C) dan wadah penampungan hampa udara (botol D) ke wadah pembidayaan tanamanserta dilakukan pengujian efektifitas alat pada budidaya tanaman (sayur kangkung)dengan mengukur tinggi tanaman dan hasil produksi tanaman, kemudian hasil pengujian diolah menggunakan Mc. Exel untuk analisis data yang telah diperoleh.

\section{Parameter yang Diukur}

1. Kapasitas Distribusi Air

Melakukan pengujian kapasitas distribusi air input dan outputselama air bersirkulasi, berhubungan dengan Debit 
$(Q)$, Volume (V) dan Waktu $(t)$ dapat menggunakan persamaan (Rizal, 2012) berikut:

$$
Q=\frac{V}{t}
$$

\section{Tekanan Hidrostatis}

Hubungan tekanan selama air bersirkulasi, Tekanan Hidrostatis (P), Massa Jenis $(\rho)$, Gravitasi (g) dan Ketinggian (h) dapat menggunakan persamaan (Kezerashvili,2010) berikut:

$$
P=\rho g h
$$

\section{Tinggi Tanaman}

Tinggi tanaman $(\mathrm{cm})$ diukur dari pangkal batang di atas permukaan tanah sampai pada titik tumbuh.

\section{Produksi Tanaman}

Produksi tanaman diukur dengan cara menimbang total tanaman yang dinyatakan dalam (g) pada akhir penelitian atau setelah tanaman berumur 14 hari setelah tanam.

\section{Proses Kerja Alat}

Sebelum alat dioperasikan terlebih dahulu wadah penampungan hampa udara (botol D) di isi air sebanyak $3.000 \mathrm{ml}$, sedangkan pada wadah penampungan hampa udara (botol C) dikosongkan atau hanya berisi udara.
Untuk menghasilkan sistem sirkulasi air maka wadah sumber air di isi air sebanyak $3000 \mathrm{ml}$, yang berada pada wadah sumber air turun ke wadah penampungan hampa udara (botol C) melalui pipa kapiler $\varnothing 0.5 \mathrm{~cm}$, sehingga memaksa udara yang berada pada wadah penampungan hampa udara (botol C) menuju ke penampungan hampa udara (botol D) sehingga menekan air yang berada pada wadah penampungan hampa udara (botol D) untuk naik ke wadah pembudidayaan tanaman (Gambar 1).

\section{Ketinggian Alat}

Ketinggian pada proses penelitian ini sangat penting, dimana $h_{1}$ lebih tinggi dibanding $h_{2}$, sehingga dapat terjadi sirkulasi air. Jika ketinggian sama atau $h_{2}$ lebih tinggi dibanding $h_{1}$, maka tidak terjadi sirkulasi air. Tinggi $h_{1}$ yaitu jarak antara permukaan air wadah sumber air dan permukaan air pada wadah penampungan hampa udara (botol C), sedangkan $h_{2 j}$ arak antara permukaan air pada wadah penampungan hampa udara (botol D) dan pipa kapiler $\varnothing 0.2 \mathrm{~cm}$ yang berada di atas wadah pembudidayaan tanaman kangkung. 


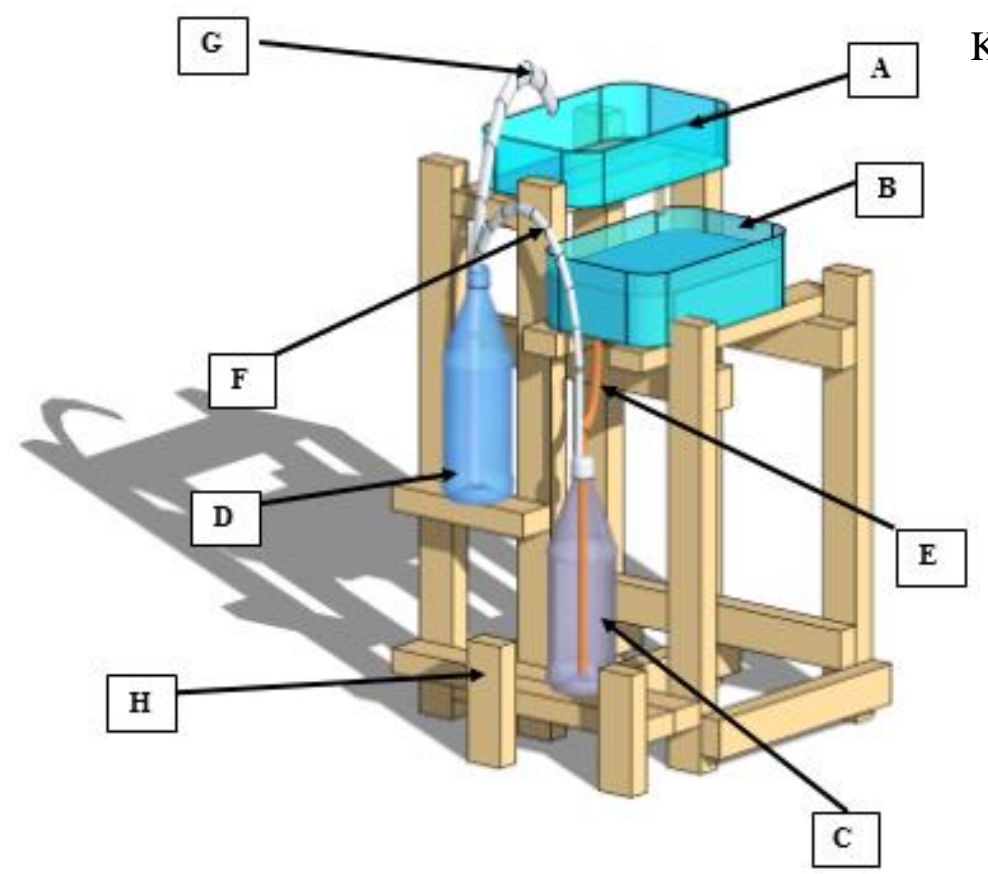

Keterangan :

A : Wadah Pembudidayaan

Tanaman.

B : Wadah Sumber Air.

C : Wadah Penampungan

Hampa Udara Berisi Udara.

D : Wadah Penampungan

Hampa UdaraBerisi Air.

E : Pipa Kapiler $\varnothing 0.5 \mathrm{~cm}$.

F : Selang Plastik $\varnothing 0.5 \mathrm{~cm}$.

$\mathrm{G}$ : Pipa Kapiler $\varnothing 0.2 \mathrm{~cm}$.

$\mathrm{H}$ : Rangka.

\section{Gambar 1.}

Desain Alat Vertikultur Sistem Hampa Udara

\section{HASIL DAN PEMBAHASAN}

\section{Tekanan Hidrostatis}

Menurut Kezerashvili (2010) ketika air pada wadah sumber air mengalir turun ke wadah penampungan hampa udara (botol C) mengikuti udara dan menghasilkan tekanan hidrostatis $P_{1}=\rho g h_{1}$. Tekanan ini memaksa udara pada wadah penampungan hampa udara (botol C) ke wadah penampungan hampa udara (botol D) akibatnya air pada wadah penampungan hampa udara (botol D) naik ke wadah pembudidayaan tanaman. Sehingga mengakitbatkan tekanan hidrostatis pada wadah penampungan hampa udara (botol D) $P_{2}=\rho g h_{2}$.

Sistem sirkulasi air pada penelitian ini terjadi saat tekanan hidrostatis pada wadah penampungan hampa udara (botol C) dan wadah penampungan hampa udara (botol D) berbeda. Tekanan hidrostatis pada wadah penampungan hampa udara (botol C) yaitu $4900 \mathrm{~kg} / \mathrm{ms}^{2}$, sedangkan tekananhidrostatis pada wadah penampungan hampa udara (botol D) yaitu $1.960 \mathrm{~kg} / \mathrm{ms}^{2}$. Rumus persamaan dapat dilihat pada Rumus (2)

Volume tidak berpengaruh pada besarnya tekanan hidrostatis, apapun bentuk wadahnya, jika ketinggiannya sama maka akan menghasilkan tekanan hidrostatis yang sama pula. Besarnya tekanan hidrostatis dipengaruhi oleh ketinggian, gravitasi dan massa jenis zat cair.

\section{Kapasitas Distribusi Input dan Output Air serta Debit Air}

Pada model sirkulasi air dengan memanfaatkan penampungan sistem hampa udara yang terdiri dari 2 saluran distribusi air yaitu input dan output. Air yang keluar dari wadah penampungan hampa udara (botol D) disebut kapasitas distribusi output dan air yang masuk ke wadah penampungan hampa udara 
(botol C) disibut kapasitas distribusi input. Gambar 1

Perhitungan volume air pada saluran input dan output dilakukan dalam 1 kali proses sirkulasi air. Hasil pengamatan dan perhitungan volume air, dapat dilihatpada Tabel 1.

Tabel 1. Volume Air

\begin{tabular}{ccc}
\hline $\begin{array}{c}\text { Input } \\
\text { (ml) }\end{array}$ & $\begin{array}{c}\text { Output } \\
\text { (ml) }\end{array}$ & $\begin{array}{c}\text { Waktu } \\
\text { (menit) }\end{array}$ \\
\hline 2025 & 1845 & 50
\end{tabular}

Berdasarkan data hasil

penelitian volume air pada Tabel 1 dapat dilihat perbedaan antara jumlah volume air input dan output yang terjadi selama 50 menit (3000 detik) yaitu jumlah air yang masuk pada botol $C$ sebanyak $2025 \mathrm{ml}$ sedangkan jumlah air yang keluar dari botol D sebanyak $1845 \mathrm{ml}$. Hal ini terjadi dikarekan saluran input

lebih besar dibandingkan dengan saluran output sehingga dapat disimpulkan bahwa proses sirkulasi air berjalan dengan baik.

Perbedaan volume air input dan output dapat dilihat setiap 5 menit dalam 1 kali siklus sirkulasi air, yang terjadi selama 50 menit. Gambar 2

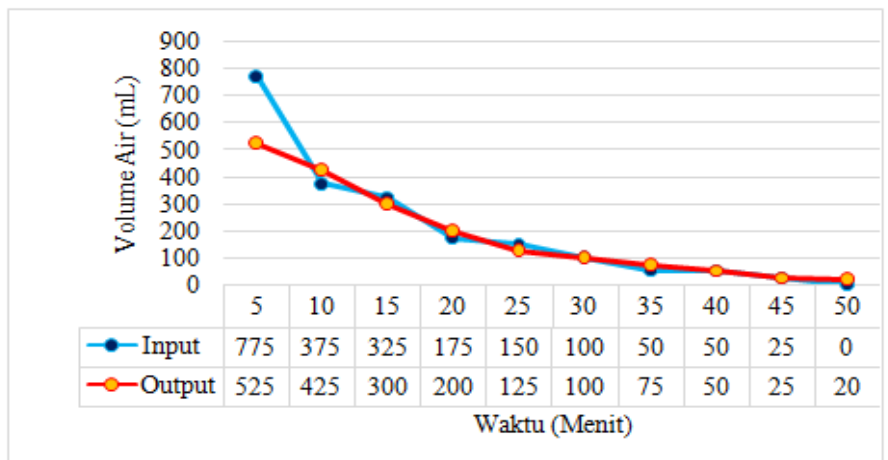

Gambar 2.

Perubahan Volume Input dan Output Setiap 5 Menit Sekali Siklus

Berdasarkan Gambar 2. dapat dilihat bahwa semakin lama proses sirkulasi air, semakin lama air yang keluar (output) maka semakin sedikit, begitu pula air yang masuk (input) semakin lama, maka semakin berkurang. Hal ini terjadi dikarenakan tekanan hidrostatis semakin berkurang atau menuju ke tekanan konstan.

Pada menit ke-50 tidak terjadi sirkulasi air, dimana air pada wadah penampungan hampa udara (botol D) tidak lagi keluar. Hal ini disebabkan tekanan pada wadah penampungan hampa udara (botol $D$ dan botol $C$ ) sama serta tekanan pada luar wadah penampungan hampa udara juga sama.

Semakin lama sirkulasi air semakin kurang lancar, maka volume air yang masuk dan volume air yang keluar juga semakin kurang begitupun debit air yang semakin berkurang. Grafik perubahan debit air setiap 5 menit (300 detik) pada 1 kali siklus sirkulasi air dapat dilihat pada Gambar 3. 


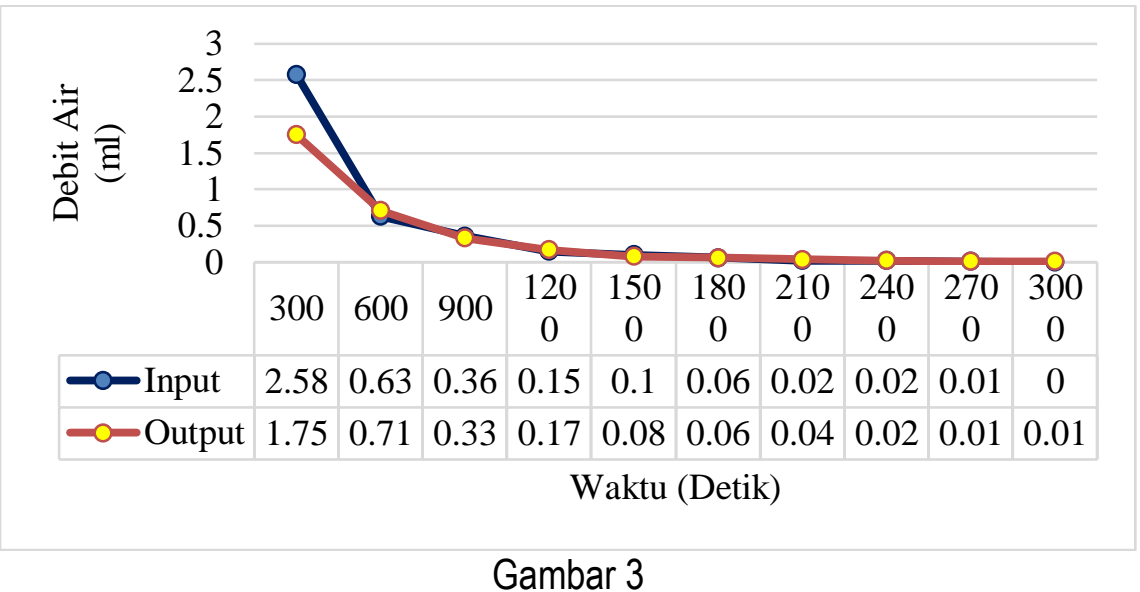

Perubahan Debit Air Input dan Debit Air Output Setiap 5 Menit Sekali Siklus

Berdasarkan Gambar 3. dapat dilihat bahwa selama proses sirkulasi air terjadi fluktuasi jumlah debit air yang masuk (input) maupun yang keluar (output). Semakin lama proses sirkulasi air, maka semakin lama debit air yang keluar pada wadah penampungan hampa udara (botol D) semakin sedikit, begitu pula pada wadah penampungan hampa udara (botol C) semakin lama, maka semakin sedikit debit air yang masuk. Hal ini terjadi dikarenakan tekanan hidrostatis semakin berkurang atau menuju ke tekanan konstan.

\section{Analisis Tanaman}

\section{Tinggi Tanaman}

Tinggi tanaman kangkung pada media tanam rockwool yang diaplikasikan pada alat vertikultur sistem hampa udara dan media tanam tanah yang dijadikan sebagai kontrol. Tinggi tanaman kangkung pada hari ke-7 dan hari ke-14, tanaman pada alat vertikultur jauh lebih meningkat perubahannya dibandingkan dengan kontrol. Rata-rata tinggi tanaman kangkung mulai dari penanaman sampai dengan 14 hari, dapat dilihat pada Gambar 4

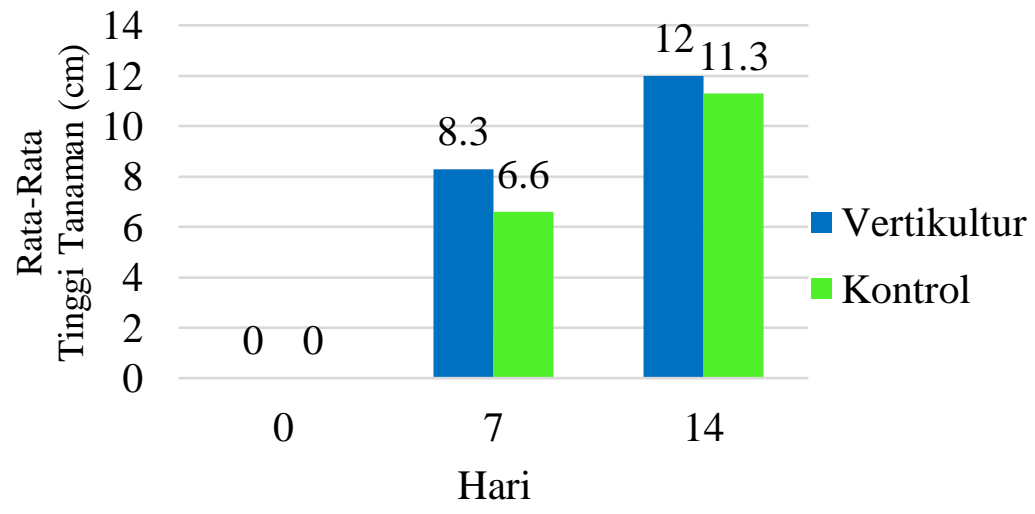

Gambar 4.

Rata-Rata Tinggi Tanaman Pada Mulai Penanaman Hingga Hari Ke-14 
Berdasarkan Gambar 4. meningkat dibandingkan dengan kontrol. menujukkan data pada hari ke-7 tinggi tanaman kangkung yang menggunakan alat vertikultur sistem hampa udara tinggi tanaman mencapai $8.3 \mathrm{~cm}$, sedangkan perlakuan kontrol hanya mencapai 6.6 $\mathrm{cm}$. Pada hari ke-14 tinggi tanaman kangkung yang menggunakan alat vertikultur sistem hampa udara tinggi tanaman mencapai $12 \mathrm{~cm}$, sedangkan perlakuan kontrol hanya mencapai 11.3 $\mathrm{cm}$. Hal ini disebabkan pada hari 0 tidak terdapat perubahan karena proses penanaman menggunakan benih. Pada hari ke-7 tanaman pada alat vertikultur perubahan tinggi tanaman sangat

Pada hari ke-14 tinggi tanaman pada alat vertikultur beda sedikit dengan kontrol. Berdasarkan hasil penelitian Rahmah (2015) menyatakan rata-rata tinggi tanaman kangkung pada hari ke-14 yaitu $6.1 \mathrm{~cm}$ dengan menggunakan media tanah hasil pembakaran.

Laju perubahan tinggi tanaman kangkung pada alat vertikultur dengan sistem hampa udara mulai penanaman sampai hari ke-14 dapat dilihat pada Gambar 4.14. sedangkan untuk laju pertumbuhan tinggi tanaman kangkung (kontrol) dapat dilihat pada Gambar 5.

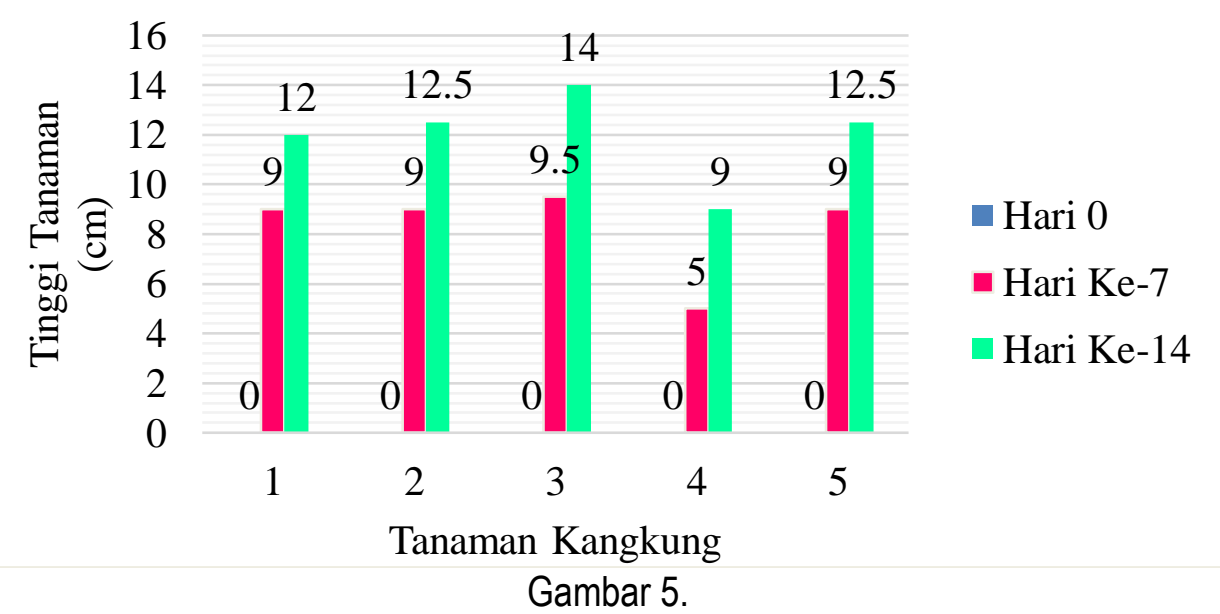

Perubahan Tinggi Tanaman Pada Alat Vertikultur Mulai Penanaman Hingga Hari Ke14

\section{Berdasarkan Gambar 5 dapat}

dilihat bahwa pertumbuhan awal tanaman kangkung sangat meningkat dikarenakan media tanam lembab. Pada hari ke-7 tinggi tanaman kangkung bervariasi, rata-rata tinggi tanaman $9 \mathrm{~cm}$, kecuali pada sampel4 mencapai $5 \mathrm{~cm}$, laju pertumbuhannya sangat lambat dibandingkan sampel lainnya. Pada hari ke-14 tinggi tanaman kangkung bervariasi, rata-rata tinggi tanaman $12 \mathrm{~cm}$, kecuali pada sampel 4 mencapai $9 \mathrm{~cm}$, laju pertumbuhannya sangat lambat dibandingkan sampel lainnya dan sampel 3 mencapai $14 \mathrm{~cm}$, laju pertumbuhannya lebih cepat dibandingkan dengan sampel lainnya. Perubahan tinggi tanaman setelah 7 hari berikutnya bertambah sekitar $3-5 \mathrm{~cm}$, namun tanaman tidak terlalu berisi dan tidak kuat karena tidak ditambahkan nutrisi selama penelitian. 


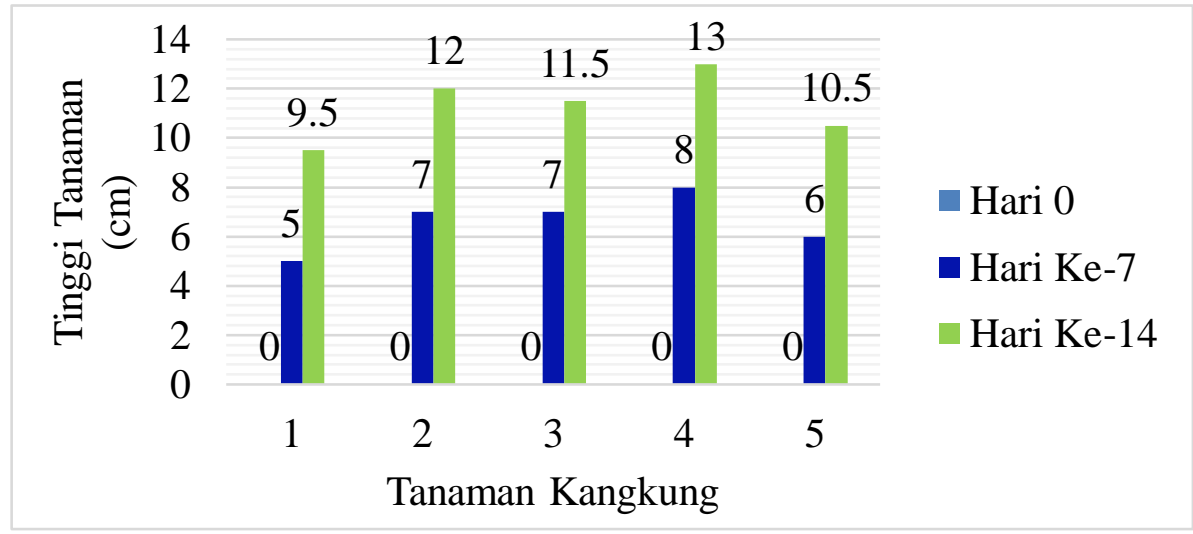

Gambar 6.

Perubahan Tinggi Tanaman Kontrol Mulai Penanaman Hingga Hari Ke14

Berdasarkan Gambar 6. dapat dilihat bahwa pertumbuhan awal tanaman kangkung tidak terlalu meningkat. Namun, perubahan tinggi tanaman setelah 7 hari berikutnya sangat meningkat. Pada hari ke-7 tinggi tanaman kangkung bervariasi, sampel 4 tinggi tanaman mencapai $8 \mathrm{~cm}$, laju pertumbuhannya cepat dibandingkan sampel lainnya. Pada hari ke-14 tinggi tanaman kangkung bervariasi, pada sampel 4 mencapai $13 \mathrm{~cm}$, laju pertumbuhannya lebih cepat dibandingkan sampel lainnya. Tanaman tidak terlalu berisi dan tidak kuat karena tidak ditambahkan nutrisi selama penelitian.

\section{Produksi Tanaman}

Benih tanaman kangkung ditanam pada 2 media tanam yaitu tanah dan rockwool. Dimana benih tanaman kangkung yang ditanam pada media tanah akan dijadikan sebagai kontrol sedangkan benih tanaman kangkung yang ditanam pada media rockwool akan dibudidayakan pada alat vertikultur sistem hampa udara.

Tanaman kangkung pada media tanam tanah (kontrol) dan rockwool (vertikultur sistem hampa udara) yang telah ditanam selama 14 hari, kemudian ditimbang per individu. Data perbandingan berat tanaman kangkung setelah 14 hari dapat dilihat pada Gambar 7.

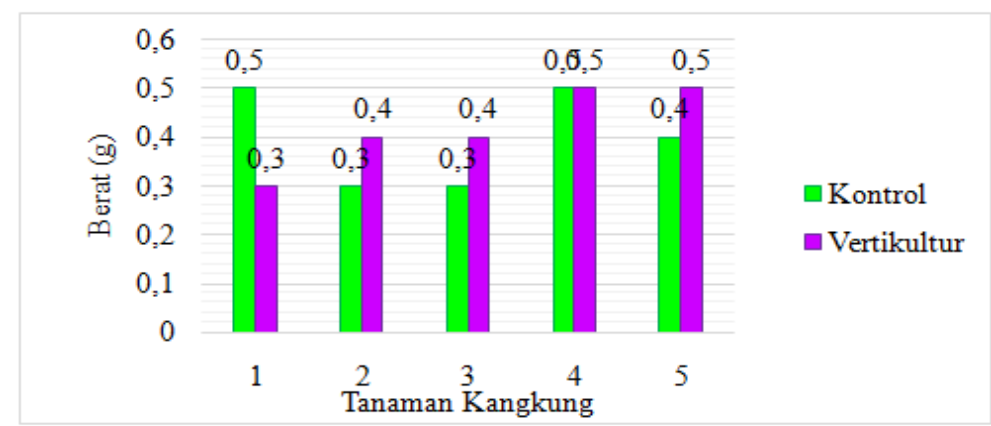

Gambar 7.

Perbandingan Berat Tanaman Kangkung (g) 14 Hari Setalah Tanam 
Berdasarkan data hasil penelitian pada Gambar 7. perbandingan berat tanaman kangkung $(\mathrm{g})$ setelah 14 hari tanam menunjukkan bahwa berat tanaman pada media tanah ataupun media rockwool berfariasi antara 0.3-0.5 g. Berat total pada tanaman kangkung dengan media tanah (kontrol) yaitu $2 \mathrm{~g}$ sedangkan berat total pada tanaman kangkung dengan media rockwool (vertikultur) yaitu $2.1 \mathrm{~g}$. Hal ini terjadi karena selama proses pembudidayaan tanaman tidak dilakukan pemberian pupuk pada tanaman.

\section{KESIMPULAN}

Berdasarkan dari hasil penelitian modivikasi tenaga pompa menjadi sistem hampa udara pada alat vertikultur, dapat diperoleh kesimpulan sebagai berikut:

1. Proses sirkulasi air berlangsung selama 50 menit (3000 detik) dalam sekali siklus sirkulasi air tekanan hidrostatis $\mathrm{P}_{1}$ sebanyak $4900 \mathrm{~kg} / \mathrm{ms}^{2}$ dan $P_{2}$ sebanyak $1960 \mathrm{~kg} / \mathrm{ms}^{2}$ sehingga menghasilkan kapasitas distribusi input air yang masuk pada wadah penampungan hampa udara (botol C) yaitu $2.025 \mathrm{ml}$ sedangkan kapasitas distribusi output air yang keluar dari wadah penampungan hampa udara (botol D) yaitu $1.845 \mathrm{ml}$ dan rata-rata debit air yang masuk pada wadah penampungan hampa udara (botol C) yaitu $0.39 \mathrm{ml} / \mathrm{dt}$ sedangkan kapasitas distribusi output air yang keluar dari wadah penampungan hampa udara (botol) yaitu $0.32 \mathrm{ml} / \mathrm{dt}$.

2. Perkembangan tanaman kangkung pada parameter tinggi tanaman menunjukan bahwa tanaman kangkung pada alat vertikultur dengan sistem hampa udara lebih cepat perubahannya dibandingkan dengan kontrol. Rata-rata tinggi tanaman 7 hari setelah tanam pada alat vertiminaponik yaitu $8.3 \mathrm{~cm}$ sedangkan kontrol $6.6 \mathrm{~cm}$ dan ratarata tinggi tanaman 14 hari setelah tanam pada alat vertikultur yaitu 12 $\mathrm{cm}$ sedangkan kontrol $11.3 \mathrm{~cm}$. Hasil produksi dari budidaya tanaman kangkung setelah 14 hari tanam pada alat vertikultur dengan sistem hampa udara seberat $2.1 \mathrm{~g}$ sedangkan hasil produksi dari budidaya tanaman kangkung dengan menggunakan media tanah yang dijadikan kontrol seberat $2 \mathrm{~g}$.

\section{DAFTAR PUSTAKA}

Balai Pengkajian Teknologi Pertanian Jakarta. 2013. Vertiminaponik, Cocok untuk Pertanian Lahan Sempit di Perkotaan, http://bbp2tp.litbang.pertanian. go. id, di akses pada tanggal 19 April 2014.

Balai Pengkajian Teknologi Pertanian Jawa Tengah, 2006, Budidaya Sayuran Dengan Vertikultur. Jawa Timur: Pusat Penelitian dan Pengembangan Peternakan.

Kezerashvili, R.Y \& Sapozhnikov.A. 2010. Magic Fountain. The City University of New York .(http://arxiv.org/pdf/physics/03 10039, di akses 10 Agustus 2016).

Lukman, L. 2008. Teknologi Budidaya Tanaman Sayuran Secara Vertikultur. Bandung: Balai Penelitian Tanaman Sayuran.

Nilam, V. 2015. Vertikultur Tanaman Selada Untuk Meningkatkan Keuntungan Di Unit Rumah Pangan Lestari (RPL) Balai 
Besar Pelatihan Pertanian

Lembang. Skripsi tidak diterbitkan. Payakumbuh: Politeknik Pertanian Negeri Payakumbuh.

Rahmah, N. 2015. Rekayasa Media Tanam Terhadap Pertumbuhan, Kelangsungan Hidupdan Produksi Sayuran. Skripsi tidak diterbitkan. Makassar. Universitas Negeri Makassar.

Rizal, M. 2012. Rancangbangun dan Uji Kinerja Sistem Kontrol Irigasi Tetes pada Tanaman Strawberry. Skripsi tidak diterbitkan. Makassar: Universitas Hasanuddin. 